\title{
Contribution of Microcredit to Artisanal Fishing in Sekondi-Takoradi Metropolis Western Region of Ghana
}

\author{
Daniel Odei Okyere (Corresponding author) \\ School of Business Studies, Takoradi Polytechnic, Ghana \\ Tel: 233-266-295-219Ｅ-mail: danookyere@yahoo.com \\ Martha Coleman \\ School of Business Studies, Takoradi Polytechnic, Ghana \\ Tel: 233-244-692-994Ｅ-mail: naadjoacole@yahoo.com
}

Emmanuel Amoateng

School of Business Studies, Takoradi Polytechnic, Ghana

Tel: 233-242-015-601Ｅ-mail: emmanuel.amoateng@tpoly.edu.gh

Received: April 20, 2016 Accepted: June 15, 2016 Published: June 22, 2016

doi: 10.5296/jsss.v3i2.9275 URL: http://dx.doi.org/10.5296/jsss.v3i2.9275

\begin{abstract}
Inadequate supply of credit is an important constraint to enhancing production in many developing countries. Making credit available to rural households in general and fishers in particular, is thus considered essential to promote economic development. This study examined how microcredit can improve output of artisanal fishers in the Sekondi-Takoradi Metropolis. Specifically, the study examined the importance of microcredit from the perspective of artisanal fishers, the effect of microcredit on the standard of living of artisanal fishers and how microcredits are utilised by artisanal fishers to enhance output. The study revealed that microcredit was an important contributor to the success of the business of the artisanal fishers.
\end{abstract}

Keywords: Contribution, Microcredit, Artisanal Fishers, Ghana 


\section{Introduction}

Fisheries contribute significantly towards food security, income and employment in many African countries. Arlinghaus, Mhner and Cowx (2002) defined fishery as "natural or 'semi natural', limnetic ecosystems, such as rivers, lakes, gravel pits, other manmade standing water bodies and reservoirs, to benefit from the use of fish and other aquatic organisms therein". Thus, fishery is any place where fishes are caught. Artisanal fishing is any kind of small-scale, low-technology, commercial or subsistence fishing practices, particularly those of coastal or island ethnic groups using traditional techniques such as rods and tackles, arrows and harpoons, throw nets and drag nets, and traditional fishing boats (Arlinghaus et al., 2002).

Small-scale fisheries provide fishing communities a means of livelihood. Fishes are sold both locally and internationally. Export of fish keeps on increasing. In 2008, world exports of fish and fishery products reached a record $\$ 102$ billion. This shows an increase of nine percent as compared to the 2007 export of $\$ 93.6$ billion (FAO, 2010). In 2008, the world consumed 115 million tonnes of fish, and demand is expected to rise. In 2008 fish as food reached an all-time high of nearly 17 kilograms per person, supplying over three billion people with at least 15 percent of their average animal protein intake (FAO, 2010). The increasing demand for fish also highlights the need for effective financing of fishing activities in order to ensure their consistent supply. Fish financing facilitates the acquisition of fishing inputs such as outboard motors, docks, boats and cold-storage facilities to augment the existing fishing tools.

According to the United States Agency for International Development [USAID] (2008), the emergence of microcredit as an alternative financial delivery mechanism to artisanal fishers was in response to the failure of efforts by government and international agencies to effectively provide financial services to fishers. According to FAO (2003), the mechanics of a microfinance operation basically involve three levels, namely, the borrowers who take out loans to invest in micro businesses, the loan delivery and recovery system, and the institution or organisation that manages the delivery system. The successful operation of these levels is premised on the twin principles of client discipline where borrowers take responsibility for their decisions and agreements made with the Microfinance Institutions (MFIs), and institutional discipline where MFIs offer and provide products and services characterised by quality, efficiency and commitment.

Microcredit is designed not only to support entrepreneurship and alleviate poverty, but also in many cases to empower micro businesses and uplift entire communities by extension (FAO, 2003). For this reason, it is worthy to examine fisherfolks' perception of the contribution of microcredit to output, using New Amanful and New Takoradi in the Sekondi-Takoradi Metropolis as a case study.

\section{Statement of the Problem}

Inadequate supply of credit is an important constraint to enhancing production in many developing countries. Making credit available to rural households in general and fishers in particular, is thus considered essential to promote economic development (Tietze \& Villareal, 2003). Over the past two decades, FAO has provided assistance to the fisheries sector in 
improving its access to institutional credit. Recent changes and developments have, however, prompted a consideration of new features in delivering credit to the sector. The most important of these relate to developments in microcredit and more recently to the commitments to the World Summit on Sustainable Development held in Rome in June 2002, which called for stepped-up investments in fisheries and increased productivity of small-scale fishers and access to productive resources (FAO, 2003).

Artisanal fisherfolks, especially those in the Sekondi-Takoradi, are directly affected by low earnings due to poor funding. Inadequate funding has resulted in the use of outmoded fishing gears resulting in low yield. According to a source at Lower Pra Rural Bank, the bank's record on borrowers showed that microcredit beneficiaries enjoy economies of scale and increased production (increased fish harvest) as a result of the availability of working capital to run their businesses. Furthermore, an interaction with the artisanal fishers in Sekondi also revealed that microcredit from the microfinance institutions have contributed immensely in the acquisition of their fishing gear and this has resulted in an increase in fish harvest. The potential of the fisheries sector to contribute to the economy and development of Ghana has not been overlooked by successive governments, but the problem of loss of employment and revenue of fishers and other ancillary service providers persist. There is the need to find a pragmatic approach to ensuring a microcredit programme that will guarantee continuous financial assistance to fishers in order to improve the artisanal fisheries sector.

\section{Objectives of the Study}

This study examines fisherfolks' perception of the contribution of microcredit to output in the Sekondi-Takoradi Metropolis. In order to facilitate the investigation, three specific objectives were considered:

1) Determine the importance of microcredit from the perspective of artisanal fishers.

2) Identify the effect of microcredit on the standard of living of artisanal fishers.

3) Identify how microcredits are utilised by artisanal fishers to enhance production.

\section{Literature Review}

\subsection{Theories of Microfinance}

According to Hulme and Mosley (1996), investments in businesses are important determinants of economic growth. Hulme and Mosley (1996) stated that there is strong and positive correlation between microcredit and improved production. This argument can be contested because microcredit cannot by itself generate income but should be perceived as an important tool in the process of developing micro-enterprises. El Solh (1999) postulates two theoretical propositions on the macro-level for supporting microcredit interventions: economic and human resources. From the economic perspective, El Solh (1999) stated that by enabling the establishment of new micro-enterprises, microfinance programmes such as microcredit, support the efficient use of labour and capital as factors of production and therefore contribute to economic growth and ultimately to sustainable development. The human resources theory is quite similar to the economic one. El Solh (1999) argued that since it is generally accepted that microcredit is labour-intensive, facilitating access to microcredit is likely to result in the acquisition of new skills and the upgrading of existing ones and thus improve on the capacity of the entrepreneurs to increase production and advance their 
wellbeing.

\subsection{Characteristics and Prospects of the Artisanal Fisheries Sector in Ghana}

The artisanal fisheries sub-sector accounts for approximately $70-80$ percent of the national marine fish production. The artisanal fishery is characterised by the use of several gears such as purse seine nets, beach seine net, set nets, drifting gill nets, hook and line as well as outboard motors. Ghana's artisanal fishing sector includes about 10,000 small, mechanised wooden boats that harvest $60-70$ percent of the marine catch (Amador, Bannerman, Quartey \& Ashong, 2006). The artisanal fishing sector is vital to food security and job creation in Ghana (USAID, 2008). Most perspectives on fisheries also suggest that the major prospects for increasing fish supplies lie in artisanal fishing. In Ghana artisanal fishing is therefore considered to be an important and integral part of agriculture/food sector development activities. Fish plays an important role in the diets of Ghanaians. It represents 60 percent of average animal protein intake, making it the single most important source of protein (USAID, 2008).

A survey of national living standards conducted between 1987 and 1999 showed that the proportion of the average household food budget spent on fish ranged from 13 - 19 percent in urban areas and $17-29$ percent in rural areas (Ghana Statistical Service [GSS], 2002). With respect to the household budget on animal products, consumption of fish accounted for about 53 percent of expenditure in urban households in 1998/1999 and in rural households, from 55 -79 percent in the three ecological zones, that is, rural coastal, rural forest and rural savannah (Seini, Nyanteng, \& Ahene, 2004). There is the need to introduce fishery policy that focuses on increasing fish yields and improved access to marketing, with a view to expanding production, increasing farm incomes, contributing to poverty reduction and creating the conditions for a viable and sustainable economic activity (Directorate of Fisheries, 2004). According to the Directorate of Fisheries (2004), features determining suitability and potential for artisanal fishery would however include availability of funds for fish inputs, market demand and price of inputs. Clearly, if artisanal fishery is to succeed in Ghana, and to play the part expected of it, then a well-structured microcredit programme needs to be instituted for their survival.

Ledgerwood (1999) defines microcredit as the provision of credit to low-income clients, including the self-employed. In the Ghanaian context, the Non-Bank Financial Institutions (NBFI) of the Bank of Ghana classify microcredit as lending to borrowers with an amount not exceeding GHS 100.00 and in the case of group lending - with joint and several guarantees of members of the group - with an amount not exceeding GHS 500.00 (Gallardo, 2002). Buyske (2004) estimates the average global microfinance loan to be around $\$ 400$ (about GH $\varnothing 1,520.00$ now). It is argued that it is poor people's inability to access formal financial services that triggered the use of innovative methods of making financial services available to them.

\subsection{Conceptual Framework}

The conceptual framework for this study took into consideration all possible factors from the literature and from observations to derive the dependent, independent and mediating variables for descriptive analysis as shown in Figure 1 below. 


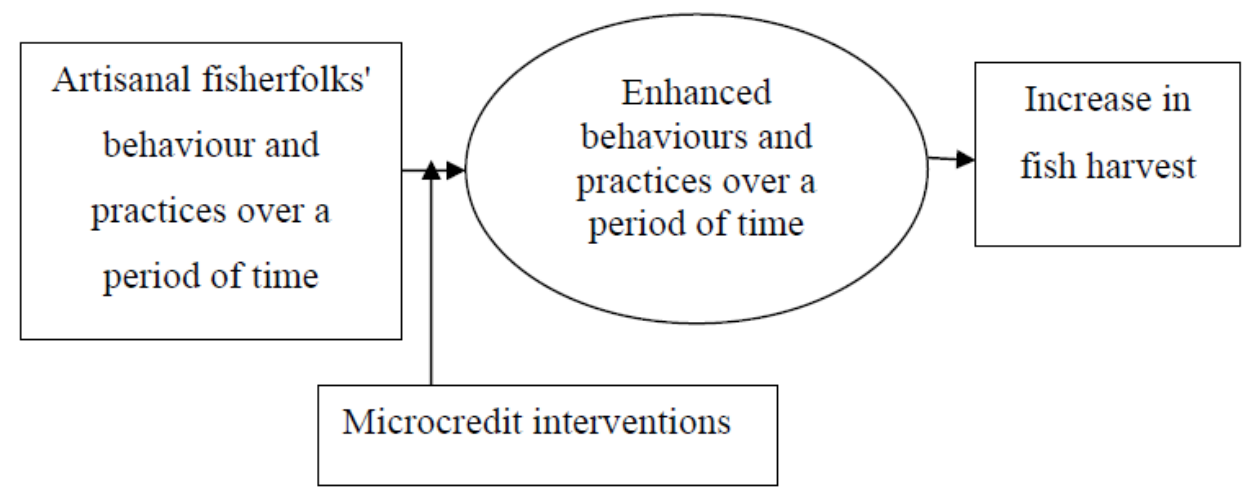

Figure 1. Conceptual framework on the contribution of microcredit to increased fish harvest of fisherfolks

Source: Adapted from Hulme (1997).

The independent variable is artisanal fisherfolks' behaviour and practices over a period of time while increase in fish harvest constitutes the dependent variable. Microcredit interventions serve as mediating variable. Artisanal fisherfolks' behaviour and practices over a period of time constitute the various behaviours and practices that fisherfolks were exhibiting when there were no microcredit packages. They sought for credit facilities from friends, family members and community leaders. These sources of credit were not enough as compared to the volume of funds required for effective investment and expansion in the fishing business. Therefore, to increase the fish harvest or output of fishers, which in the long run increase their income levels and standard of living, they turned to microcredit institutions for financial support.

The argument of this study is that when fisherfolks have access to microcredit facilities, the interventions of this credit facility will enhance the behaviour and practices of fisherfolks over a period of time. Some of these enhanced behaviour and practices include increase in investment through purchasing of new and quality net, acquisition of new outboard motors and expanding the fishing business. This will help increase the fish output or fish harvest of the fisherfolks which in the long run will increase their income level and standard of living. Artisanal fisherfolks' behaviours and practices as indicated in the literature are determined by many factors including social, psychological and economic factors.

The general argument is that with appropriate financial interventions by microcredit institutions, these fisherfolks are likely to enhance or modify their behaviours and practices and this will increase their output significantly. This argument is informed by the economic theory of microcredit interventions. It therefore, means that with appropriate financial packages designed by microcredit institutions to support fisherfolks within the Sekondi-Takoradi Metropolis will result in increased output. This will in turn increase their income level and standard of living respectively. With significant increase in income and microcredit support, these fisherfolks can re-invest some of their income, which may increase their capital formation with a corresponding expansion in their businesses. 


\section{Methodology}

\subsection{Research Design}

A case study research design was employed for this study to investigate fisherfolks' perception on how microcredit contributes to output (production) of artisanal fisheries of the Sekondi-Takoradi Metropolis. The case study research design enables the researcher to unearth solutions to the research problem and provides a guide throughout the various stages of the research. It is seen as the field strategy, procedure and the steps that help the investigator to seek information and analyse his evidence in the scientific way (Sharma \& Lawrence, 2005). From the work of Yin (2003), a case study approach is based on a constructivist paradigm. Constructivists claim that truth is relative and that it is dependent on one's perspective.

\subsection{Population}

The population of interest was all registered artisanal fishers and rural banks that provide microcredit to artisanal fishers in the Sekondi-Takoradi Metropolis. However, the accessible population was all registered artisanal fisherfolks of Lower Pra Rural Bank within the Sekondi-Takoradi Metropolis. The study population also included operations manager of the bank who can provide the needed information for the study. Current records from the bank show that there are 200 registered artisanal fisherfolks in New Amanful and New Takoradi, two of the towns in the metropolis (Lower Pra Rural Bank [LPRB] Limited, 2013).

\subsection{Sample and Sampling Procedure}

A sample size of 132 was selected for the study using simple random sampling procedure. According to Ary, Jacobs, Razavieh and Sorensen (2006), the most used approach for determining the sample in a case study is to specify the precision of estimation desired and then to determine the necessary sample size. Researchers usually sample from an accessible population and hope to generalise to a target population. This study used both probability and non-probability techniques to select the required number of respondents. The catchment communities of the artisanal fisherfolks were identified purposively (thus communities with 20 or more registered fisherfolks) while the lottery method of simple random sampling was used to select two communities within the catchment of Sekondi-Takoradi thus, New Takoradi and New Amanful.

The lottery method of simple random sampling technique was used to select individual registered fisherfolks. According to the Universal Accreditation Board (2003), 132 will be a perfect representation of a population of 200 hence the choice of 132 registered fisherfolks as the sample size was appropriate. The 132 sample size can be confirmed by the formula developed by the National Education Association (1960) as follows:

$\mathrm{s}=\chi^{2} \mathrm{~N} \mathrm{P}(1-\mathrm{P}) \div \mathrm{d}^{2}(\mathrm{~N}-1)+\chi^{2} \mathrm{P}(1-\mathrm{P})$.

Where:

$\mathrm{s}=$ required sample size.

$\chi^{2}=$ the table value of chi-square for 1 degree of freedom at the desired confidence level $1.96^{2}(3.841)$.

$\mathrm{N}=$ the population size of 200 . 
$\mathrm{P}=$ the population proportion (assumed to be .50 since this would provide the maximum sample size).

$\mathrm{d}=$ the degree of accuracy expressed as a proportion (.05).

$\mathrm{s}=1.96^{2} \times 200 \times 0.5(1-0.5) \div 0.05^{2}(200-1)+1.96^{2} \times 0.5(1-0.5)$

$\mathrm{s}=132$

Furthermore, the purposive sampling procedure was used to handpick Lower-Pra Rural Bank Limited. Purposive sampling was used because amongst the rural banks in Sekondi-Takoradi, it is the rural bank in the Sekondi-Takoradi Metropolis which devotes most of its funds to artisanal fishers. After Lower Pra Rural Bank was selected, the operations manager in charge of credits was selected purposively. This is because he was an expert in microcredit and the best person to give the needed information.

\subsection{Data Collection}

The data collected involved issues bordering on artisanal fisherfolks level of production and the contribution of microcredit to fish harvest. The data collected were both quantitative and qualitative. Both primary and secondary sources of data were used for the study. The primary data were responses obtained from the artisanal fishers and the operations manager. The secondary sources of data were those obtain from the bank's records section, its annual reports, books and journals on microcredit.

\subsection{Instruments Design}

This study employed interview schedule to gather information from the artisanal fisherfolks and interview guide for the operations manager of Lower Pra Rural Bank Limited. Interview schedule was used because majority of the artisanal fisherfolks were not able to read and write. Interview guide for the operations manager was used to elicit data from the operations manager of Lower Pra Rural Bank.

\subsection{Data Analysis}

The data collected were first transcribed and grouped into various themes based on the objective of the study. However, the close-ended items were already coded in the instruments. The data were further edited. After the editing, the Statistical Package for Service Solutions was used to code the data. The analyses of the responses were done verbatim to the close and open-ended items in the interview schedules and the interview guide. Essentially, the study adopted mainly qualitative approaches of data analysis.

\section{Results and Discussion}

\subsection{Background Characteristics of the Respondents}

This section deals with a distribution of the respondents by community, sex, age group, marital status and household size. With regard to occupation, all the respondents selected for the study were artisanal fishers. Cross tabulation was used to analyse the data. The results on respondents' background characteristics are presented in Tables 1, 2 and 3.

The sex distribution of respondents by their community is presented in Table 1 below. 
Table 1. Sex distribution of respondents by community

\begin{tabular}{lllllll}
\hline \multirow{2}{*}{ Respondents } & \multicolumn{2}{l}{ Respondents community } & \multicolumn{2}{c}{ Total } \\
\cline { 2 - 5 } & \multicolumn{2}{l}{ New Amanful } & New Takoradi & & \\
\cline { 2 - 5 } & Freq. & $\%$ & Freq. & $\%$ & Freq. & $\%$ \\
\hline Male & 27 & 65.9 & 72 & 79.1 & 99 & 75.0 \\
Female & 14 & 34.1 & 19 & 20.9 & 33 & 25.0 \\
Total & 41 & 100 & 91 & 100 & 132 & 100 \\
\hline
\end{tabular}

Source: Field data, 2014.

As contained in Table 1, $41(31.1 \%)$ of the respondents were selected from New Amanful while 91 (68.9\%) were selected from New Takoradi. This shows that majority of the respondents were selected from New Takoradi. Table 1 further shows that majority $(75.0 \%)$ of the registered artisanal fishers of Lower Pra Rural Bank Limited in New Amanful and New Takoradi were males while 25.0 percent were females. Again, the data shows that most of the respondents in New Amanful (65.9\%) and New Takoradi (79.1\%) were males. The findings show that more male artisanal fishers deal with the bank than the female artisanal fishers. Therefore, more male artisanal fishers are qualified to secure microcredit from the bank as compared to the female artisanal fishers since their number in terms of registered customers are more than the females.

The next background characteristics of respondents analysed was their age group. The age distribution of the artisanal fishers is depicted in in Table 2.

Table 2. Age distribution of respondents

\begin{tabular}{lllllll}
\hline \multirow{2}{*}{ Age group of respondents } & \multicolumn{2}{l}{ New Amanful } & \multicolumn{2}{l}{ New Takoradi } & \multicolumn{2}{c}{ Total } \\
\cline { 2 - 7 } & Freq. & $\%$ & Freq. & $\%$ & Freq. & $\%$ \\
\hline $18-35$ years & 23 & 56.1 & 49 & 53.8 & 72 & 54.5 \\
$36-53$ years & 7 & 17.1 & 16 & 17.6 & 23 & 17.5 \\
Above 53 years & 11 & 26.8 & 26 & 28.6 & 37 & 28.0 \\
Total & 41 & 100 & 91 & 100 & 132 & 100 \\
\hline
\end{tabular}

Source: Field data, 2014.

Table 2 shows that majority of the respondents from Amanful (56.1\%) and New Takoradi $(53.8 \%)$ were within the age group of $18-35$ years. Furthermore, 28.0 percent of the respondents were above 53 years old. The findings indicate that majority $(54.5 \%)$ of the respondents were youth. It therefore, means that the future of the artisanal fishing business is bright since more youth have channelled their energies and resources into the fishing business. 
The third background characteristic shows the family size of the respondents. It also shows the marital status of the respondents. This is shown in Table 2 below:

Table 3. Household size distribution of respondents by marital status

\begin{tabular}{llllllll}
\hline Household size of respondents & \multicolumn{3}{l}{ Marital status } & \multicolumn{3}{c}{ Total } \\
\cline { 2 - 6 } & \multicolumn{2}{l}{ Single } & \multicolumn{3}{l}{ Married } & & \\
\cline { 2 - 5 } & Freq. & $\%$ & Freq. & $\%$ & Freq. & $\%$ \\
\hline $1-3$ people & 14 & 30.4 & 25 & 29.1 & 39 & 29.5 \\
$4-6$ people & 12 & 26.1 & 23 & 26.7 & 35 & 26.5 \\
7 people and above & 20 & 43.5 & 38 & 44.2 & 58 & 44.0 \\
Total & 46 & 100 & 86 & 100 & 132 & 100 \\
\hline
\end{tabular}

Source: Field data, 2014.

As shown in Table 3 above, $86(65.2 \%)$ of the respondents are married while $46(34.8 \%)$ are single (not married). Relatively, more $(44.2 \%)$ of the respondents who were married had family size above six. Similarly, 43.5 percent of the respondents who were single were from a household size of seven and above. This shows that 44.0 percent of the respondents have large family sizes.

\subsection{Importance of Microcredit from the Perspective of Artisanal Fisherfolks}

The first substantive objective of the study focused on the importance of microcredit from the perspective of artisanal fisherfolks within the Sekondi-Takoradi Metropolis. Through the interview process many statements were used to elicit data from the respondents. In relation to this objective, the study first elicited data on the importance of microcredit from the perspectives of the artisanal fishers. Most of the artisanal fishers (120 of the respondents) indicated that they have benefited from the bank's microcredit for more than one year. The chief fishermen of New Amanful asserted that borrowers are required to repay their loan within six months. Depending on ones' bargaining power the repayment period can be spread over a maximum period of one year. He added:

Regarding those microcredit interventions designed for investment in the fishing business, the bank has people or workers who supervise, monitor and evaluate the activities of the fishers and also give them suggestions as to what equipment or materials to buy. Instead of giving the artisanal fishers cash, the bank sometimes supply these materials and equipment (outboard motors, fishing net, canoes and so on) to the fishers on credit (18 ${ }^{\text {th }}$ January, 2014).

The above comment confirms what the operations manager stated that the bank has been given microcredit to the artisanal fisherfolks in the Sekondi-Takoradi Metropolis for the past 14 years in different forms and packages (cash and fishing inputs). The operations manager added that with regard to the fishing business, the microcredit package available to artisanal fishers is an investment package, and the focus of this package is to help them secure equipment and materials that will enhance their fish harvest and income in the long run. 
Majority (83\%) of the respondents admitted that the availability of microcredit was very important because it enables them to acquire their fishing inputs for enhanced production. They added that microcredit has boosted their capacity to invest in their fishing business. The chief fisherman of New Amanful stated that the microcredit packages given to the fishers help them increase their fish harvest. The views of the respondents corroborate with the comments of Hulme and Mosley (1996) that there is strong and positive correlation between microcredit and improved production.

\subsection{Effect of Microcredit on the Standard of Living of Artisanal Fishers}

The respondents were first asked to indicate whether they think microfinance loans have had effect on their children's education. In conducting the interview, emphasis was on the effect of Lower Pra Rural Bank microcredit interventions on respondents improved standard of living. At the end of the interview sessions, it was realised that all but one of the respondents admitted that the bank's microcredit packages have had positive impact on their children's education. Thus, they were able to invest their funds borrowed into the fishing business, which resulted in increased profit. These profits were used to pay their children's fees and cater for the basic necessities of their homes.

\subsection{Utilisation of Microcredits by Artisanal Fishers to Enhance Production}

The third objective of the study was to look at how artisanal fishers use microcredit with regard to their production level. The comments of the respondents show that most artisanal fishers use the microcredit facilities to purchase fishing craft/gear and other fishing related equipment and repair to enhance their activity and increase production. Specifically, the chief fisherman in New Takoradi stated that most fishermen are able to re-invest what they get from their fishing business in other non-fishing business. Generally, the findings show that artisanal fishers use microcredit loans judiciously and efficiently. The findings are in line with the assertions of Simanowitz and Brody (2004) who argued that microcredits affect production positively.

\section{Conclusions}

The findings revealed that microcredit plays a significant role in enhancing the artisanal fishers' production level, and also their standard of living as a whole in the communities. This is because the access and utilisation of microcredit services by the artisanal fishers has given them the opportunity to get access to capital to expand their fishing business, buy new and modern fishing inputs, and as a result increase their incomes. This increased income in turn led to the artisanal fishers boosting their life chances and standard of living by contributing financially to the household up-keep, payment of utility bills, accessing quality healthcare and education.

Access to and utilisation of microcredit facilities provided by Lower Pra Rural Bank Limited has posed challenges to the artisanal fishers but the benefits outweigh the challenges, hence the study concludes that microcredit has contributed positively on artisanal fishers' production level. Based on the findings of the study it can be concluded that microcredit contributes significantly to artisanal fishers' output level in Sekond-Takoradi Metropolis. The findings confirm that microcredit plays a vital role in output levels of artisanal fishers in Sekondi-Takoradi Metropolis. The importance and benefits that accrue to the artisanal fishers 
have been explicitly discussed and it is important to note that the study will provide one of the very first resource books for loan officers, policy makers and development workers in the field of microcredit in New Amanful and New Takoradi Metropolis.

\section{Recommendations}

Based on the key findings and conclusions of this study, it is recommended to the operations manager that he should request management of Lower Pra Rural Bank Limited to ensure that:

- The bank spreads the microcredit repayment period to cover two years in order reduce the undue pressure on the fisherfolks during repayment.

- The bank organises management training programmes for artisanal fishers to enrich their knowledge on financial management. This should be done before the microcredit is granted to them.

The artisanal fishers in the communities are also advised to ensure that:

- They support each other with management skills, supervision and monitoring as a group.

- They should appeal to the government to get involved in controlling the interest rates in microcredit institutions. The government can do this by establishing financial institutions that grant microcredit at reduced interest rates.

\section{References}

Amador, K., Bannerman, P., Quartey, R., \& Ashong, R. (2006). Ghana canoe frame survey. Journal for Marine Fisheries Research Division of Ghana, 34, 43-44.

Ary, D., Jacobs, L. C., Razavieh, A., \& Sorensen, C. (2006). Introduction to research in education (7th ed.). Journal of Research on Technology in Education, 47(1), 1-21 http://dx.doi.org/10.1080/15391523.2015.967542

Arlinghaus, R., Mhner, T., \& Cowx, I. G. (2002). Reconciling traditional inland fisheries management and sustainability in industrialised countries. Hull: International Fisheries Institute, University of Hull.

Buyske, G. (2004). Microfinance: Part 1: Little but mighty. The RMA Journal, 58-61.

Directorate of Fisheries (2004). Fish development policy. Ghana: Directorate of Fisheries.

El Solh, C. F. (1999). Feasibility and operationalization of microfinance facilities: Theoretical perspectives and practical considerations. New York: United Nations.

Food and Agriculture Organisation [FAO] (2003). The state of world fisheries and aquaculture in 2002. Rome: FAO Fisheries and Aquaculture Department.

Food and Agriculture Organisation [FAO] (2010). Regional review on status and trends in aquaculture development in Sub-Saharan Africa. Rome: FAO.

Gallardo, J. (2002). A framework for regulating microfinance institutions: The experience in Ghana and the Philippines. Washington D.C: World Bank. http://dx.doi.org/10.1596/1813-9450-2755

Ghana Statistical Service [GSS] (2002). Ghana living standards survey on the pattern and trends of poverty in Ghana. Ghana: Assembly Press.

Hulme, D., \& Mosley, P. (1996). Finance against poverty. London: Routledge.

Jain, P. S. I. (1996). Managing credit for the rural poor: Lessons from the Grameen Bank. 


\section{Macrothink}

World Development, 2(1), 79-89. http://dx.doi.org/10.1016/0305-750X(95)00116-T

Ledgerwood, J. (1999). Microfinance handbook: An institutional and financial perspective. Washington D.C: World Bank.

Remenyi, J., \& Quinones, B. (Eds.) (2000). Microfinance and poverty alleviation: Case studies from Asia and the Pacific. New York: Unique Press.

Seini, A. W., Nyanteng, V. K., \& Ahene, A. A. (2004). Policy dynamics, trends in domestic fish production and implications for food security in Ghana: A report prepared for FAO of the United Nations. Accra, Ghana: Africa Regional Office.

Sharma, U., \& Lawrence, S. (2005). Public sector reform, Global trends versus local needs: The case of a state rental organisation in Fiji. Journal of Accounting and Organisational Change, 1(1), 141-164. http://dx.org/10.1108/18325910510635335

Simanowitz, A., \& Brody, A. (2004). Realising the potential of microfinance, Insights, 51, $1-2$.

Tietze, U., \& Villareal, L. V. (2003). Microfinance in fisheries and aquaculture: Guidelines and case studies. FAO Fisheries Technical Paper, 440, 114. Retrieved January 23, 2013, from http://www.fao.org/docrep/006/ Y5043E/Y5043E00.HTM

Universal Accreditation Board (2003). Table for determining random sample size from a given population. Accreditation Study Course Handout, 16.

United States Agency for International Development [USAID] (2008). West African fishery profiles. Dakar: FAO.

Yin, R. K. (2003). Case study research: Design and methods. New York: Sage Publishing.

\section{Copyright Disclaimer}

Copyright for this article is retained by the author(s), with first publication rights granted to the journal.

This is an open-access article distributed under the terms and conditions of the Creative Commons Attribution license (http://creativecommons.org/licenses/by/3.0/). 